www.jmscr.igmpublication.org

Index Copernicus Value: 79.54

ISSN (e)-2347-176x ISSN (p) 2455-0450

crossrefDOI: https://dx.doi.org/10.18535/jmscr/v7i2.09

\title{
Knowledge, perception and involvement of men in family planning in rural communities of Cross River State, Nigeria
}

\author{
Authors \\ Ekpenyong, Nnette Okon ${ }^{1}$, Omoronyia, Ogban Ezukwa ${ }^{1}$, Agbor. Iwasam Elemi ${ }^{1}$, \\ Nwoha Doris Charles ${ }^{2}$ \\ ${ }^{1}$ Department of Community Medicine, University of Calabar/ University of Calabar Teaching Hospital, \\ Calabar, Cross River State, Nigeria
}

${ }^{2}$ Department of Community Medicine, University of Calabar Teaching Hospital, Calabar, Cross River State,

Nigeria

Corresponding Author

Ekpenyong, Nnette Okon

Department of Community Medicine, University of Calabar/ University of Calabar Teaching Hospital,

Calabar, Cross River State, Nigeria

Phone no 2348037237979, nnekon2015@gmail.com

\begin{abstract}
Family planning has been described as the best approach to quicken achievement across Sustainable Development Goal themes of People, Planet, Prosperity, Peace, and Partnership. Unmet need for family planning remains very high regardless, especially in rural areas.This study assesses the knowledge and involvement of men in family planning in rural communities in Cross River State, Nigeria. Multistage sampling method was used to recruit 220 men in rural communities of Cross River State aged 15- 59 years who were in a union. Although the level of awareness of family planning among respondents was high(96.2\%), adequate knowledge of family planning methods was poor(89.9\%); the practice of family planning was poor - condom use as a method of family planning practiced by $37.2 \%$, withdrawal by $1.4 \%$, while no respondent had undergone male vasectomy.

Bivariate analysis revealed: religion was statistically significantly associated with knowledge of pills as a family planning method ( $p=0.008)$ : Catholics were less likely to be knowledgeable about pills: occupation was significantly associated with family planning practice among respondents $(p=0.015)$. Respondents who were students, recent school leavers or unemployed (66.7\% in all) practiced family planning more than those who were government- (34.4\%) or self-employed (36.4\%) $(p=0.015)$. Despite recognition and recommendation of male involvement during the International Conference on Population and Development (ICPD), male participation in this service is still very poor in the rural area.

Keywords: Male, involvement, family planning, rural.
\end{abstract}

\section{Introduction}

Family planning is defined by the World Health Organisation (WHO) as a way of thinking and living that is adopted voluntarily, upon the basis of knowledge, attitude and responsible decisions by individuals and couples in order to promote the 
health and welfare of the family group and thus contribute effectively to the social development of a country. ${ }^{1}$

Africa accounts for about one tenth of the world's population and 20 per cent of global births; yet, nearly half of the mothers who die during pregnancy and childbirth are from this region. The World Health Organization (WHO) estimates that poor reproductive health accounts for up to 18 per cent of the global burden of disease, and 32 per cent of the total burden of disease for women of reproductive age. One of the underlying causes of this situation is the lack of access to key intervention for improving reproductive health, such as family planning. ${ }^{2}$

Despite the fact that family planning does not only help to reduce fertility rate, reduce maternal morbidity and mortality, prevent mother to child transmission of HIV, it is also described as the best approach that can fasten achievement across the five (5) Sustainable Development Goal themes of People, Planet, Prosperity, Peace, and Partnership $^{3}$ yet still only 13.4 percent of currently married women in Nigeria are using a method of family planning, and 27.6 percent of currently married women have unmet need for $\mathrm{FP},{ }^{4}$ rural women are twice less likely compared to urban women to use a method of contraception (10 percent versus 21.1percent). In Cross River State, $77 \%$ of couples are not using any Family Planning method, with an unmet need for child spacing at $18.1 \%$ and family limiting at $8 \%$. $^{4}$

Despite tremendous advances in the development of safer and more effective contraceptives and in the provision of affordable and accessible family planning services, millions of individuals and couples around the world are unable to plan their families as they wish. It is estimated that 137 million couples worldwide still have an unmet need for family planning ${ }^{5}$ these could probable account for the high mortality from complications of pregnancy, childbirth and unsafe abortion.

Nigeria like most traditional society is patriarchal in nature. ${ }^{6}$ Men in Nigeria possess high decisionmaking power and often are the primary decision makers regarding women's health. A survey carried out in Nigeria showed that more than half of the married women's health care decisions were made by their husbands. ${ }^{7}$ However, most family planning methods, as well as most efforts to promote their use, have focused on the women although, recently there has been growing recognition that men significantly influence reproductive decisions and play an important role in family planning practices. This decision power should be channeled towards making informed and quality decisions towards the promotion of reproductive health.

It is against this background that this study seeks to assess the involvement of men in family planning in rural communities in Cross River State, Nigeria.

\section{Methodology}

This study was carried out in Cross River State which is one of the six states in South-South Geopolitical zone of Nigeria, with Calabar as the state capital. There are eighteen Local Government Areas (LGAs) in Cross River State out of these 11 are classified as rural based on Cross River State planning Commission. Cross River State is bounded in the South by the Atlantic Ocean, East by Cameroon, North by Benue State, West by Abia and Akwa Ibom State. According to the 2006 national census figures, Cross River State has a total population of 2,892,988: $1,471,967$ males and 1,421,021 females $^{8}$

The main ethnic group of the inhabitants of Cross River state are the Efiks, Ejegham and Bekwerra. Other ethnic groups include the Quas, Ibibios, Igbos, Yorubas and Hausas. Christianity is the most predominant religion in the study settings. The main occupations are subsistent fishing, farming, trading and working in government establishments.

This was a community based descriptive analytical study to assess the knowledge, perception and involvement of men in family planning in rural communities in Cross River 
State. The study population were male members of the community aged $15-59$ years who are in a union (either married, cohabitating or in a steady relationship with a girl). Two hundred and twenty respondents were selected using a multistage sampling method, simple random sampling was used to select the study Communities, the households were selected through systematic sampling method, if there was more than one eligible man in a household then simple random sampling was used to select one respondent. Informed consent/assent was sought and given before administration of the questionnaire.

Apre-tested semi-structured interviewer administered questionnaire adapted from selected aspect of the 2013National Demographic and Health Survey (NDHS) was used to collect data on the study variable. The variables in the questionnaire included sociodemographic variables such as age, sex, marital status, occupation, religion, educational status, and ethnic grouping. Other variables included knowledge of family planning methods, perception of men towards family planning and the practice of family planning among men in the selected communities. Data generated from the study was managed with STATA $^{\mathrm{TM}}$, Version 12. Excel was used to plot graphs. Demographic information of respondents was described by way of means (quantitative variables) and frequencies (qualitative variables).

The data for this study were collected in keeping with the declaration of Helsinki. Informed consent was obtained from all the respondents.

\section{Result}

Questionnaires were administered to two hundred and twenty respondents, two hundred and eighteen (218) questionnaires, giving a response rate of $99.1 \%$. Refusal to complete the interview accounted for the non-response rate. The mean age of respondent was $29.1 \pm 8.4$, with the age group 25-34 years having the largest representation $(38.5 \%)$. Farmers $(31.7 \%)$, traders $(25.7 \%)$ or civil servants $(12.0 \%)$ made up majority of the respondents. Most of the men were
Christians of the Pentecostal faith (55.5\%), others were protestants $(32.6 \%)$ and catholic $(11.0 \%)$. Majority of the respondents were married (42.6\%), with a mean number of children the respondent had as $3.2 \pm 2.5$. Also the mean number of children the respondent desire to have was $5.83 \pm 2.4$ with a median of 6.0 and a range of 3 to15.

Table 1: Socio-Demographic Variables of the Respondents

\begin{tabular}{|c|c|}
\hline Variable & $\begin{array}{c}\text { Control } \\
n=218(\%)\end{array}$ \\
\hline \multicolumn{2}{|l|}{ Age (years) } \\
\hline $15-24$ & $79(36.2)$ \\
\hline $25-34$ & $84(38.5)$ \\
\hline $35-44$ & $44(20.1)$ \\
\hline $45-54$ & $11(5.0)$ \\
\hline Mean $\pm \mathrm{SD}$ & $29.1 \pm 8.4$ \\
\hline Median (range) & $28(18-52)$ \\
\hline \multicolumn{2}{|l|}{ Education } \\
\hline Primary & $57(26.1)$ \\
\hline Secondary & $128(58.7)$ \\
\hline Tertiary & $33(15.1)$ \\
\hline \multicolumn{2}{|c|}{ Religion/Denomination } \\
\hline Pentecostal & $121(55.5)$ \\
\hline Protestant & $71(32.6)$ \\
\hline Catholic & $24(11.0)$ \\
\hline Traditional & $2(0.9)$ \\
\hline \multicolumn{2}{|l|}{ Occupation } \\
\hline Farming & $69(31.7)$ \\
\hline Sales/trade & $56(25.7)$ \\
\hline Civil servant & $26(12.0)$ \\
\hline Others* & $24(11.0)$ \\
\hline Technician & $22(10.0)$ \\
\hline Artisan & $15(6.8)$ \\
\hline Professional & $6(2.8)$ \\
\hline \multicolumn{2}{|l|}{ Marital status } \\
\hline Married & $93(42.6)$ \\
\hline Cohabiting & $76(34.9)$ \\
\hline Single & $43(19.7)$ \\
\hline Separated & $1(0.5)$ \\
\hline Widowed & $5(2.3)$ \\
\hline Divorced & $0(0.0)$ \\
\hline $\begin{array}{l}\text { Mean number } \\
\text { of children } \\
\text { respondents have }\end{array}$ & $3.2 \pm 2.5$ \\
\hline Median (range) & $3.0(0-11)$ \\
\hline $\begin{array}{l}\text { Mean number of } \\
\text { children } \\
\text { respondents wish } \\
\text { to have }\end{array}$ & $5.83 \pm 2.4$ \\
\hline
\end{tabular}

Median (range) $\quad 6.0(3-15)$

*Others refer to those in school, recent school leavers and unemployed. 
Table 2 shows that $38.1 \%$ of respondent were knowledgeable about condom/diaphragm as a method of family planning, However, 4.1\%, $22.3 \%, 3.2 \%$ and $8.3 \%$ of respondents were knowledgeable about IUCD, pills, implants and male sterilization as family planning methods .

For natural methods of family planning, $7.8 \%$ and $10.1 \%$ of respondents were knowledgeable of periodic abstinence and withdrawal as methods of family planning

Table 2: Knowledge of Men Regarding Family Planning Methods

\begin{tabular}{|c|c|}
\hline Variable & $\begin{array}{l}\text { Frequency } \\
\mathbf{n}=218(\%)\end{array}$ \\
\hline \multicolumn{2}{|l|}{ Pills } \\
\hline Yes & $49(22.3)$ \\
\hline No & $169(77.7)$ \\
\hline \multicolumn{2}{|l|}{ IUCDs } \\
\hline Yes & $9(4.1)$ \\
\hline No & 209 (95.9) \\
\hline \multicolumn{2}{|l|}{ Injections } \\
\hline Yes & 45 (20.6) \\
\hline No & $173(79.4)$ \\
\hline \multicolumn{2}{|l|}{ Implants } \\
\hline Yes & $7(3.2)$ \\
\hline No & $211(96.8)$ \\
\hline \multicolumn{2}{|c|}{ Condom/diaphragm } \\
\hline Yes & $83(38.1)$ \\
\hline No & $135(61.9)$ \\
\hline \multicolumn{2}{|c|}{ Female sterilization } \\
\hline Yes & $4(1.8)$ \\
\hline No & $214(98.2)$ \\
\hline \multicolumn{2}{|c|}{ Male sterilization } \\
\hline Yes & $18(8.3)$ \\
\hline No & 200 (91.7) \\
\hline \multicolumn{2}{|c|}{ Periodic abstinence } \\
\hline Yes & $17(7.8)$ \\
\hline No & $201(92.2)$ \\
\hline \multicolumn{2}{|c|}{ Total abstinence } \\
\hline Yes & $7(3.2)$ \\
\hline No & $211(96.8)$ \\
\hline \multicolumn{2}{|c|}{ Withdrawal } \\
\hline Yes & $22(10.1)$ \\
\hline No & $196(89.9)$ \\
\hline
\end{tabular}

Table 3 shows that the respondent's perception regarding family planning was poor, as $64.7 \%$ of respondents thought that contraceptive was a woman's business, women may become promiscuous if the use contraceptives $(57.3 \%)$ and women should be the ones to use contraceptives $(65.1 \%)$.
Table 3: Perception Of Men Regarding Family Planning Among Respondents

\begin{tabular}{|l|c|}
\hline Variable & $\begin{array}{c}\text { Frequency } \\
\text { n=218(\%) }\end{array}$ \\
\hline $\begin{array}{l}\text { Contraception is } \\
\text { women's business }\end{array}$ \\
$\quad$ Agree & $141(64.7)$ \\
$\quad$ Disagree & $77(35.3)$ \\
Women may become & \\
promiscuous & \\
$\quad$ Agree & $125(57.3)$ \\
$\quad$ Disagree & $93(42.7)$ \\
Women should be the ones to & \\
use contraceptives & \\
$\quad$ Agree & \\
$\quad$ Disagree & $142(65.1)$ \\
\hline
\end{tabular}

Table 4: shows that the practice of family planning among respondents was poor, only $37.2 \%$ of respondents used condom as a method of family planning, $1.4 \%$ of men used withdrawal method and none of the respondents had undergone male sterilization

Table 4: Family Planning Practices among Respondents

\begin{tabular}{|c|c|}
\hline Variable & $\begin{array}{c}\text { Frequency } \\
n=218(\%)\end{array}$ \\
\hline \multicolumn{2}{|l|}{ Pills } \\
\hline Yes & $8(3.7)$ \\
\hline No & $210(96.3)$ \\
\hline \multicolumn{2}{|l|}{ IUCDs } \\
\hline Yes & $1(0.5)$ \\
\hline No & $217(99.5)$ \\
\hline \multicolumn{2}{|l|}{ Injections } \\
\hline Yes & $21(9.6)$ \\
\hline No & $197(90.4)$ \\
\hline \multicolumn{2}{|l|}{ Implants } \\
\hline Yes & $5(2.3)$ \\
\hline No & $213(97.7)$ \\
\hline \multicolumn{2}{|c|}{ Condom/diaphragm } \\
\hline Yes & $80(37.2)$ \\
\hline No & $138(62.8)$ \\
\hline \multicolumn{2}{|c|}{ Female sterilization } \\
\hline Yes & $0(0.0)$ \\
\hline No & $218(100.0)$ \\
\hline \multicolumn{2}{|c|}{ Male sterilization } \\
\hline Yes & $0(0.0)$ \\
\hline No & $218(100.0)$ \\
\hline \multicolumn{2}{|c|}{ Periodic abstinence } \\
\hline Yes & $7(3.2)$ \\
\hline No & $211(96.8)$ \\
\hline \multicolumn{2}{|c|}{ Withdrawal } \\
\hline Yes & $3(1.4)$ \\
\hline No & 215 (98.6) \\
\hline
\end{tabular}


Table 5: shows that at the bivariate level, religion was statistically associated $(\mathrm{p}=0.008)$ with knowledge of pills as a family planning method. Catholics were less likely to be knowledgeable about pills as a method of family planning.

Table 5: Factors Associated with Knowledge of Pills as a Family Method among Respondents

\begin{tabular}{|c|c|c|c|c|}
\hline \multirow[t]{2}{*}{ variable } & \multicolumn{4}{|c|}{ Frequency $n=218(\%)$} \\
\hline & $\begin{array}{c}\mathrm{Yes}(\%) \\
\mathrm{n}=51\end{array}$ & $\begin{array}{l}\text { No(\%) } \\
n=167\end{array}$ & $\chi^{2}$ & $\begin{array}{c}\text { p- } \\
\text { value }\end{array}$ \\
\hline Age group & & & & \\
\hline $15-24$ & $19(24.1)$ & $60(75.9)$ & Fisher's & 0.920 \\
\hline $25-34$ & $18(21.4)$ & $66(78.6)$ & exact & \\
\hline $35-44$ & $11(25.0)$ & $33(75.0)$ & test & \\
\hline $45-54$ & $3(27.2)$ & $8(72.8)$ & & \\
\hline Marital status & & & & \\
\hline Cohabiting & $20(26.3)$ & $56(73.7)$ & 1.821 & 0.402 \\
\hline Married & $23(24.7)$ & $70(75.3)$ & & \\
\hline Others & $8(16.3)$ & $41(83.7)$ & & \\
\hline $\begin{array}{l}\text { Number of children } \\
\text { respondents have }\end{array}$ & & & & \\
\hline $0-4$ & $35(22.9)$ & $118(77.1)$ & Fisher's & 0.673 \\
\hline $5-9$ & $14(23.3)$ & $46(76.7)$ & exact & \\
\hline $10-14$ & $3(60.0)$ & $2(40.0)$ & test & \\
\hline $\begin{array}{l}\text { Number of children } \\
\text { respondents wish to } \\
\text { have }\end{array}$ & & & & \\
\hline $0-4$ & $19(23.5)$ & $62(76.5)$ & 6.3765 & 0.828 \\
\hline $5-9$ & $26(22.4)$ & $90(77.6)$ & & \\
\hline $10-15$ & $6(28.6)$ & $15(71.4)$ & & \\
\hline Education & & & & \\
\hline Primary & 11(19.3) & $46(80.7)$ & 2.8988 & 0.235 \\
\hline Secondary & $35(27.3)$ & $93(72.7)$ & & \\
\hline Tertiary & $5(15.1)$ & 28(94.9) & & \\
\hline Occupation & & & & \\
\hline Govt-employed & $7(21.9)$ & $25(78.1)$ & & \\
\hline Self-employed & $39(24.1)$ & $123(75.9)$ & 0.171 & 0.918 \\
\hline Others & $5(20.8)$ & $19(79.2)$ & & \\
\hline +Religion & & & & \\
\hline +Catholic & $1(4.2)$ & 23(95.8) & & \\
\hline Pentecostal & $30(24.8)$ & $91(75.2)$ & Fisher' & 0.008 \\
\hline Protestant & $18(25.4)$ & $53(74.6)$ & s exact & $*$ \\
\hline Traditional & $2(100.0)$ & $0(0.0)$ & test & \\
\hline
\end{tabular}

Table 6 shows that at the bivariate level, occupation was statistically significantly associated with family planning practice among respondents. $(\mathrm{P}=0.015)$

Respondents who were students, recent school leavers or unemployed $(66.7 \%)$ practiced family planning more than those who were government employed (34.4\%) or self- employed (36.4\%). This difference was statistically significant. $\mathrm{P}=$ 0.015

Other socio-demographic characteristics namely, age, marital status, educational level, religion, ethnicity and number of children (have or desired) did not significantly influence family planning practice.

Table 6: Factors Associated with Family Planning Practice of use of Condom Among Respondents

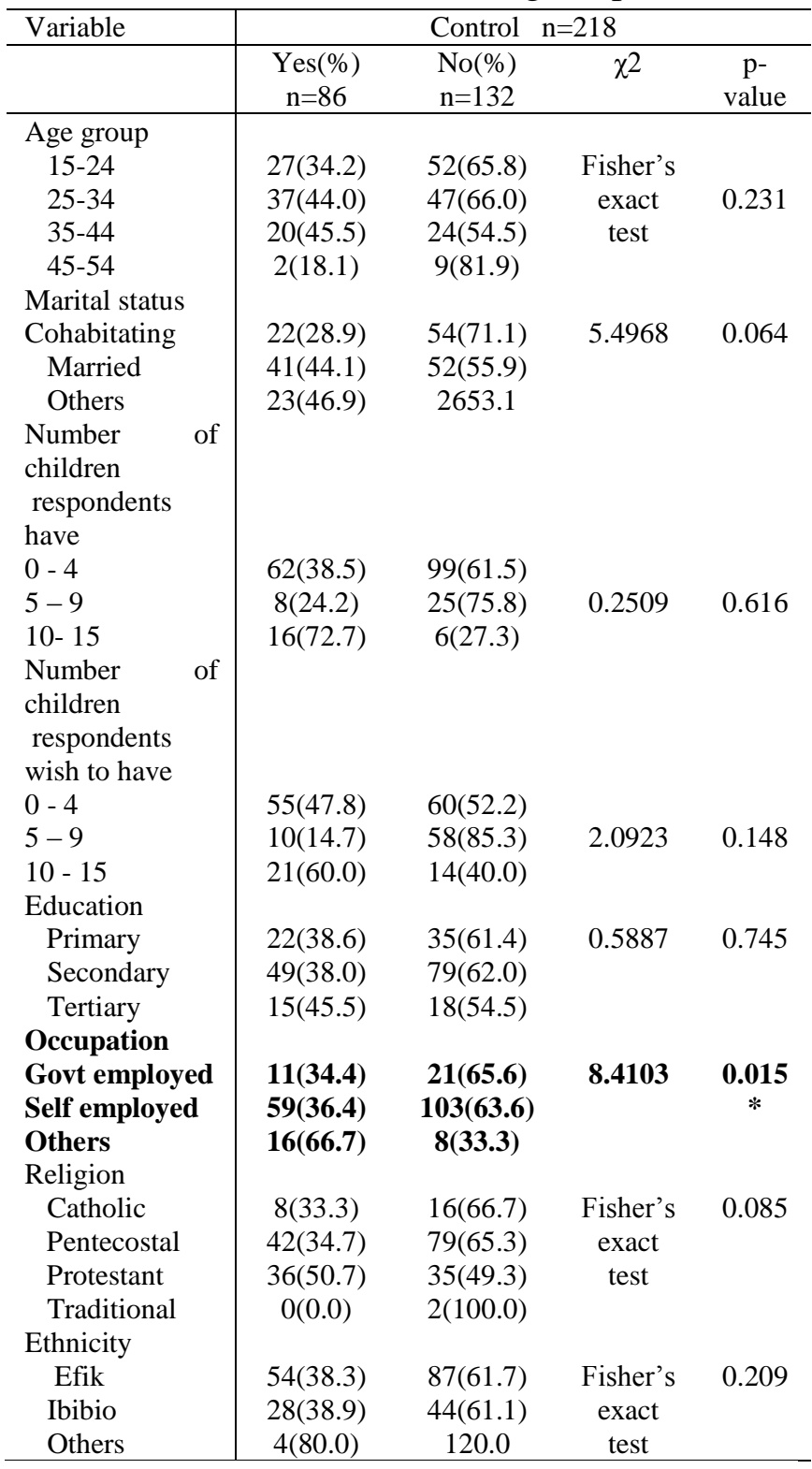

\section{Discussion}

This was a community based study aimed at assessing the knowledge, perception and involvement of men in FP in a rural community in Cross River State.

The level of awareness of family planning among respondent was very high (100\%), this may be due to the recent Task Shifting Task Sharing Policy (TSTSP) of the Cross River State government, ${ }^{9}$ and it is similar to that found in an earlier study of rural men in Ibadan(90.9\%) ${ }^{10}$ and in in Ilorin, 
Kwara state where nearly all men $(96.5 \%)$ were aware of family planning. ${ }^{11}$ Also similar to a study in Jordan $(98 \%)^{12}$ but it is much higher than that found in a study among the Yoruba where only about $65 \%$ of men interviewed knew of at least one contraceptive method ${ }^{13}$

The high level of poor knowledge of men regarding the different family planning method is comparable to the reported male knowledge on specific family planning from a national baseline survey ${ }^{14}$ and a study in Kano. ${ }^{15}$ The findings of this study were however much lower than the level of knowledge on family planning noted in a study conducted in Kwara state, south west Nigeria. ${ }^{11}$ The large disparity may be because majority of the men in the south west are more enlightened, have a higher literacy level and are less restricted by socio-cultural norms that may prevent their participation.

Perception of the respondent to FP and STI prevention was generally poor. More than half of the respondent believed that contraception is a woman's business and that women may become promiscuous if the use contraceptives and $64.7 \%$ agree that women should be the ones to use contraceptives this is similar to a study in Kwara State where a moderate proportion of men supported the FP concept ${ }^{11}$ and in a national survey where about $66.6 \%$ of men believe that the women should be the ones to use contraceptives ${ }^{16}$ but contrary to what was found in a previous study in India where about half of the men have positive attitude and they seemed to encourage their spouses to adopt family planning. ${ }^{17}$ More-so a study done in Calabar associated positive attitude towards contraceptives to its actual usage. ${ }^{18}$ This might be the reason for the poor practice of contraceptive use in the area and the resultant large family size.

The level of participation of men in family planning was generally poor. Condoms which is a common male dependent method of family planning, have been used $34.9 \%$ of the time by respondents in this study for family planning, these was comparable to a previous study among
Nigeria undergraduates and among young men in sub-Saharan Africa ${ }^{19}$ but much higher than what was gotten in a previous study in Niger state $(12.5 \%)^{20}$

Practice of other male controlled FP methods like Withdrawal $(1.9 \%)$, periodic abstinence $(2.8 \%)$ and male sterilization $(0 \%)$ was also low, may be because they respondents lack adequate knowledge of these methods.

More-so none of the respondents or their partners used any permanent method of family planning, this may be due to cultural, religious and psychosocial beliefs. $^{21,22,23}$

Use of injection by female partners for family planning was $9.9 \%$ this was much lower than what was gotten in a study in Ethiopia (91.0\%). ${ }^{24}$

The results of this study showed that at bivariate level, men who were Pentecostal, protestant, and traditionalist were more knowledgeable of pills as a family planning methods than those who were Catholics. This may be because catholic discourages all forms of family planning that is not natural.

\section{Conclusion}

Despite the recognition and recommendation during the ICPD and subsequent global population conferences of the importance of involving men in family planning, this assessment of men's knowledge, perception and participation in this service is poor

Source of support - self sponsored

\section{References}

${ }^{1}$ Saluja N, Sharma S, Choudhary S, Gaur D. et al, Contraceptive Knowledge, Attitude and Practice Among Eligible Couples of Rural Haryana. The Internet Journal of Health. 2011; 12(1)

${ }^{2}$ Tigest K. Reproductive health in the African region: what has been done to improve the situation? UN Chronicle. Dec 2007 
${ }^{3}$ Starbird E, Norton M, Marcusa R. Investing in Family Planning: Key to Achieving the

Sustainable Development Goals. Global Health: Science and Practice.2016;4(2) www.ghspjournal.org Accessed 20/11/18

${ }^{4}$ National Bureau of Statistics (NBS) and United Nations Children's Fund (UNICEF). Multiple Indicator Cluster Survey 2016-17, Survey Findings Report. Abuja, Nigeria: National Bureau of Statistics and United Nations Children's Fund. 2017

${ }^{5}$ World Health Organization.Promoting family Planning. Available from www.who.int/reproductive

health/topics/family_planning/en

${ }^{6}$ Makama G. Patriarchy and gender inequality in Nigeria: the way forward European Scientific Journal. 2013;(17) Available from www.eujournal.org Accessed 24/11/18

7 National Population Commission (NPC) [Nigeria] and ICF Macro. Nigeria Demographic and Health Survey 2008. Abuja, Nigeria: National Population Commission and ICF Macro. 2009.

${ }^{8}$ FGN. National Population Commission, Population Census. Abuja, Nigeria. 2006

${ }^{9}$ Population Council.Enhancing Frontline Healthworkers' abilities to improve MNCHservices in Cross River State. 2017. Available from www. Popcouncil.org. Accessed $01 / 2019$

${ }^{10}$ Lawoyin TO, Osinowo H, Babatunde $\mathrm{M}$, Bajomo TG, Betiku AO, Biakolo, Busari KT, Fehintola A. .Family planning in rural Nigeria: a study among men.Afr J Med Med Sci. 2002;31(2):159-62

${ }^{11}$ Odu OO, Ijadunola KT, Komolafe JO, Adebimpe WT. Men's knowledge of and attitude with respect to family planning in a suburban Nigerian community. niger J Med. 2006 JulSep;15(3):260-5.

12 Petro-Nustas W.Men's Knowledge of and Attitudes Toward Birthspacing and Contraceptive Use in Jordan.International Family Planning Perspectives. 1999;25(4)
${ }^{13}$ Adewuyi A, Ogunjuyigbe P. The Role of Men in Family Planning: An Examination of Men's Knowledge and Attitude to Contraceptive Use among the Yorubas. African Population Studies/Etude de la Population Africaine. 2003;18(1):35-49

14 Keating J. Nigeria Reproductive Health, Child Health, and Education Baseline Household Survey, 2005.Measure Evaluation. October 2006 ${ }^{15}$ Duze MC. Mohammed IZ. MaleKnowledge, Attitudes and FamilyPlanningPractices in Northern Nigeria. Afr J ReprodHealth 2006; 10(3): 53- 65.

${ }^{16}$ Odimegwu C. Family planning attitude and use in Nigeria:a factor analysis. International Family Planning Perspective 1999,25(2)

17 Varma G. R, Rohini A. Attitude of Spouse towards Family Planning: A Study among Married Men and Women of a Rural Community in West Godavari District, Andhra Pradesh. Anthropologist. 2008; 10(1): 71-75

${ }^{18}$ Bassey EA, Abasiattai AM, Asuquo EE, Udoma EJ, Oyo-lta A. Awareness, attitude and practice of contraception among secondary school girls in Calabar, Nigeria. Niger J Med. 2005 AprJun;14(2):146-50.

${ }^{19}$ Arowojolu AO, Ilesanmi, A.O , Roberts O.A, OkunolaM.A. Sexuality, Contraceptive Choice and AIDS Awareness among Nigerian Undergraduates.Afr J Reprod Health 2002; 6(2): $60-70$

${ }^{20}$ Sunmola A.M, Dipeolu, M, Babalola, S. Adebayo O.T, Reproductive Knowledge, Sexual Behaviour and Contraceptive Use among Adolescents in Niger State of Nigeria. African Journal of Reproductive Health 2003; 7(1) April: $37-48$

${ }^{21}$ Ebeigbe P.N, Igberase G.O, Eigbefoh J. Vasectomy: A Survey of Attitudes, Counseling Patterns and Acceptance among Nigerian Resident Gynaecologists. Ghana Med J. 2011 September; 45(3): 101-104 
${ }^{22}$ Jegede A.S, Odumosu O. Gender and Health Analysis of Sexual Behaviour in South-Western Nigeria, African Journal of Reproductive Health, Vol. 7, No. 1, April, 2003 pp. 63-70

${ }^{23}$ Bogale B, Wondafrash M, Tilahun T, Girma E. Married women's decision making power on modern contraceptive use in urban and rural southern Ethiopia. BMC Public Health 2011, $11: 342$

${ }^{24}$ Adwoba A.R, Sossou, M. Attitudes toward and use of knowledge about family planning among Ghanaian men. International Journal of Men's Health, 2008. 